ISSN: 2146-3042

DOI: $10.25095 / \mathrm{mufad} .934240$

\title{
Sürdürülebilir Sigortacılık İçin Sürdürülebilirlik Açıklamaları: BİST Sigorta Şirketleri Faaliyet Raporlarının İçerik Analizi *
}

\author{
Gülsün İŞSEVEROĞLU**
}

\section{ÖZET}

Sektörel yapıları gereği ekonominin tüm dinamiklerinin sorumluluğunu üzerinde taşıyan sigorta şirketlerinin, kurumsal sürdürülebilirlik kriterlerine uygun rapor hazırlamaları ve karar vericilerin bilgisine sunmaları özel bir önem taşımaktadır. Sigorta şirketlerinin ekonomide kilit konumda olma özelliği, sürdürülebilirlik unsurlarını açıklamalarının önemini bir kat daha artırmaktadır. Çalışmada, Borsa İstanbul'da yer alan sigorta şirketlerinin kurumsal sürdürülebilirlik açıklamalarının "Küresel Raporlama Girişimi" ilkelerine uygunluğu, nitel araştırmaya dayalı içerik analiziyle ele alınmıştır. Çalışma ile şirketlerin sürdürülebilirlik ilkelerine uyumu ve sektörün kendine özel niteliklerinin getirdiği sürdürülebilirlik unsurlanı faaliyet raporlarına dayanarak, karar vericiler için faydacılık yaklaşımıyla değerlendirilmiştir.

Anahtar Kelimeler: Sürdürülebilirlik Raporlaması, Sürdürülebilir Sigortacılık, Küresel Raporlama Girişimi

JEL Sinıflandırması: M14, M41, M49.

\section{Sustainability Statements for Sustainable Insurance: Content Analysis of BIST} Insurance Companies Annual Reports

\section{ABSTRACT}

It is of special importance that insurance companies, which bear the responsibility of all the dynamics of the economy due to their sectoral structures, prepare reports in accordance with corporate sustainability criteria and present them to the decision-makers. The fact that insurance companies are in a key position in the economy further increases the importance of explaining the sustainability factors. In the study, the compliance of the corporate sustainability statements of the insurance companies in Borsa Istanbul with the principles of the "Global Reporting Initiative" was discussed with content analysis based on qualitative research. With the study, the compliance of companies with the principles of sustainability and the sustainability elements brought by the specific characteristics of the sector were evaluated with a utilitarian approach for decision makers based on the annual reports.

Keywords: Sustainability Reporting, Sustainable Insurance, Global Reporting Initiative Jel Classification: M14, M41, M49.

\footnotetext{
${ }^{*}$ Makale Gönderim Tarihi: 31.03.2021, Makale Kabul Tarihi: 13.07.2021 , Makale Türü: Nitel Araştırma

** Doç. Dr., Bursa Uludağ Üniversitesi, Mustafakemalpaşa Meslek Yüksekokulu, gissever@uludag.edu.tr, ORCID:0000-0002-5942-1278.
} 


\section{GíRiş̧}

Kurumsal sürdürülebilirlik muhasebenin en temel kavramlarından biridir. Kurumsal yolculukta sürdürülebilirlik raporları, kurumsal strateji ve uzun vadeli hedefleri kapsamasıyla bilgi kullanıcılarının bilgiyi değerlendirmesine ışı tutan kilit bir platform oluşturmaktadır. Kurum içindeki bilgi kullanıcılarının kurumsal vizyonu içselleştirmelerini ve bu bağlamda önlemler ve aksiyonlar almalarını sağlamaktadır. Kurum dışındaki bilgi kullanıcıları nezdinde, faaliyetlerin etkisini göstermeye yönelik aktif etkisiyle kurumun itibarını artırmaya hizmet etmektedir.

Küresel Raporlama Girişimi'nin (Global Reporting Initiative -GRI), kriterleri ile belirlenen ve uluslararası boyutta da geniş yer bulan sürdürülebilirlik raporu standartlarına göre, Borsa İstanbul'da (BİST) pay senetleri işlem gören sigorta şirketlerinin sürdürülebilirlik açıklamalarının faaliyet raporlarından izlenmesi çalışmanın amacını oluşturmaktadır. GRI, bir kuruluşun ekonomik, çevresel ve sosyal etkileriyle ilgili bilgileri raporlamak için kullanılan bir standartlar setidir. Çalışmada öncelikle kurumsal sürdürülebilirlik bağlamında kavramsal çerçeveye yer verilmiş ve finans sektörünün en önemli ayağından birini oluşturan sigorta sektörüne özel sürdürülebilirlik düzenlemeleri üzerinde durulmuştur. Sürdürülebilirliğin önemli göstergeleri olan sosyal ve çevresel bildirimlerin niteliği ve karar vericilere sunulan boyutu faaliyet raporlarından içerik analiziyle elde edilmiş ve bulgular değerlendirilmiştir.

\section{KURUMSAL SÜRDÜRÜLEBILLIRLIKK BAĞLAMINDA KAVRAMSAL ÇERÇEVE}

Kurumsal raporlamanın ilk ayağını oluşturan finansal raporlamayı 1903 yılında, U.S. Steel isimli Amerikan çelik şirketi gerçekleştirmiştir (www.pwc.com,2020). Bir asırdan daha fazladır on binlerce şirket için rutin hale gelen finansal raporlama geçmiş bilgilerin geleceğe aktarılmasına aracılık etmiş̧ir. On yıllardır bireysel ve kurumsal yatırımcılar için öncelikli konu ise, kurumların finansal üstünlüğü olmuştur. Ancak küresel çapta yaşanan politik krizler, ekolojik dengenin tahrifatı, ekonomik dezenformasyon, etik değerlerin dejenerasyonu 1980'li yıllarda kurumsal sosyal sorumluluk (KSS) ve çevresel farkındalığ öne çıkarmış ve pradigma kaymasını başlatmıştır. Geçmişin verileriyle hazırlanan faaliyet raporları geleceğe yatırım yapan yatırımcıları reaktif tepkiden proaktif tutuma yöneltmiştir. Londra'nın ev sahipliğinde Birleşmiş Milletler'in öncülüğünde (1987) düzenlenen Dünya Çevre ve Kalkınma Komisyonu'nda sunulan Brundtland Raporu ise, kurumsal sürdürülebilirlik akımını başlatmıştır.

Sürdürülebilirlik kavramı ile ilgili olarak, "sürdürülebilirlik", "kurumsal sosyal sorumluluk" "entegre raporlama" gibi farklı isimler ve tanımlar verilmiştir (Roca ve Searcy, 2012:103-118). Farklı tanımlar kullanılsa da, kurumların sosyal ve çevresel, niteliksel ve niceliksel kazanımlarını içeren ve karar vericilerin bilgi gereksinimlerini karşılayan sürdürülebilirlik raporlarının, 20. yüzyılın başlarında başta Amerika, İngiltere, Avusturya gibi ülkelerdeki bazı kuruluşlar tarafından, finansal raporları desteklemek amacıyla düzenlendiği görülmektedir (Maltby, 2004:415-439). Başlarda ağırlıklı olarak sosyal değerler ve çalışma şartlarıyla ilgili bilgi sunan sürdürülebilirlik raporları 80 'li yılların son çeyreğinde çevresel sorunlara doğru eğilim göstermiş, 90'lı yıllarda Küresel Raporlama Girişimi ile profesyonel raporlama düzenlemeleri başlamıştır (Kolk, 2010: 367-374). 
Küresel Raporlama Girişimi, kuruluşların ekonomik, sosyal ve çevresel etkilerini iletmek için küresel ortak dil sağlayarak, sorumluluk almalarını sağlayan bağımsız uluslararası bir kuruluştur. GRI, Exxon Valdez petrol sızıntısının çevreye verdiği zarar nedeniyle halkın tepkisini takiben 1997 yılında Birleşmiş Milletler Çevre Programı (United Nations Environment Programme-UNEP) ve Çevreye Duyarlı Ekonomiler Koalisyonu (Coalition for Environmentally Responsible Economies CERE) tarafindan Boston'da kurulmuştur. Küresel ölçekte sürdürülebilir raporlamanın en önemli insiyatifi konumundaki GRI, sürdürülebilir bir gelecek yaratabilmek için kuruluşların çevresel davranış ilkelerine bağlı kalması adına, toplumsal boyutta hesap verebilirlik mekanizmasını oluşturmak ve sorumluluk almalarını sağlamak amacını taşımaktadır. 2000 yılında yayınlanan GRI k1lavuzlarının (G1) ilk versiyonunu sonraki yıllarda 2002 (G2), 2006 (G3) ve 2013 (G4) izlemiştir. 2016 yılında GRI, kılavuz ilkelerden sürdürülebilirlik raporlamasına geçmiş ve ilk küresel standartları belirlemiştir. GRI Standartları; vergi (2019) ve atık (2020) konularını da kapsamak üzere güncellenmeye ve eklenmeye devam etmektedir (https://www.globalreporting.org, 2020).

GRI tarafindan çerçevesi çizilen sürdürülebilirlik raporları, bir kuruluşun ekonomik, çevresel ve/veya sosyal etkileriyle sürdürülebilir bir geleceğe yönelik olumlu veya olumsuz katkıları hakkında kamuoyunu bilgilendirme eylemidir. İçinde bulunduğu toplumun bir parçası olan kuruluşların, ekonomi, çevre ve toplum üzerindeki önemli etkilerini küresel olarak kabul edilmiş bir standarda göre açıklamaları beklenmektedir. GRI standartları, küresel karşılaştırılabilirliği ve bilgi kalitesini artırmak, böylece kuruluşların daha fazla şeffaflığını ve hesap verebilirliğini sağlamak için tasarlanmıştır. Sürdürülebilirlik raporları, iç ve dış paydaşların fikir oluşturmasına ve geleceğe yönelik bilinçli kararlar almasına hizmet etme anlayışına dayanmaktadır.

GRI standartları, bir kuruluşun sürdürülebilirlik raporu hazırlamasına yardımcı olmak üzere bir dizi birbiriyle ilişkili standartlar setinden oluşmaktadır. GRI 100 serisi üç evrensel standart içermektedir (www.globalreporting.org, 2020).

GRI 101: GRI standartları setini kullanmak için temel başlangıç noktasıdır. GRI 101, rapor içeriğini ve kalitesini tanımlamak için raporlama ilkelerini belirler. GRI Standartlarına uygun olarak bir sürdürülebilirlik raporu hazırlamak için gereksinimleri içerir ve GRI standartlarının nasıl kullanılabileceğini ve bunlara nasıl başvurulabileceğini açıklar. GRI 101, standartlara uygun bir sürdürülebilirlik raporu hazırlayan kuruluşlar ve belirli bilgileri raporlamak için seçilen GRI standartlarını kullananlar için gerekli olan özel iddiaları da içerir.

GRI 102: Bir kuruluşun sürdürülebilirlik raporu hakkındaki bağlamsal bilgilerini raporlamak için yararlanılan genel bildirimlerdir. Kuruluşun profili, stratejisi, etik ve dürüstlüğü, yönetişimi, paydaş katılım uygulamaları ve raporlama süreciyle ilgili bilgileri içerir.

GRI 103: Kuruluşun öncelikli bir konuyu nasıl yönettiğine ilişkin bilgileri raporlamak için kullanılan yönetim yaklaşımıdır. Sürdürülebilirlik raporundaki her bir öncelikli konu için kullanılmak üzere tasarlanmıştır. GRI 103, her bir öncelikli konunun neden önemli olduğu, etkilerinin başlangıcı ve bu etkilerin nasıl yönettiğine dair bir açıklama sunulmasına olanak tanır. Konuya özel Standartlar "Ekonomik-200, “çevre konular1-300”, "Sosyal konular-400” serilerini içermektedir (Şekil 1) 


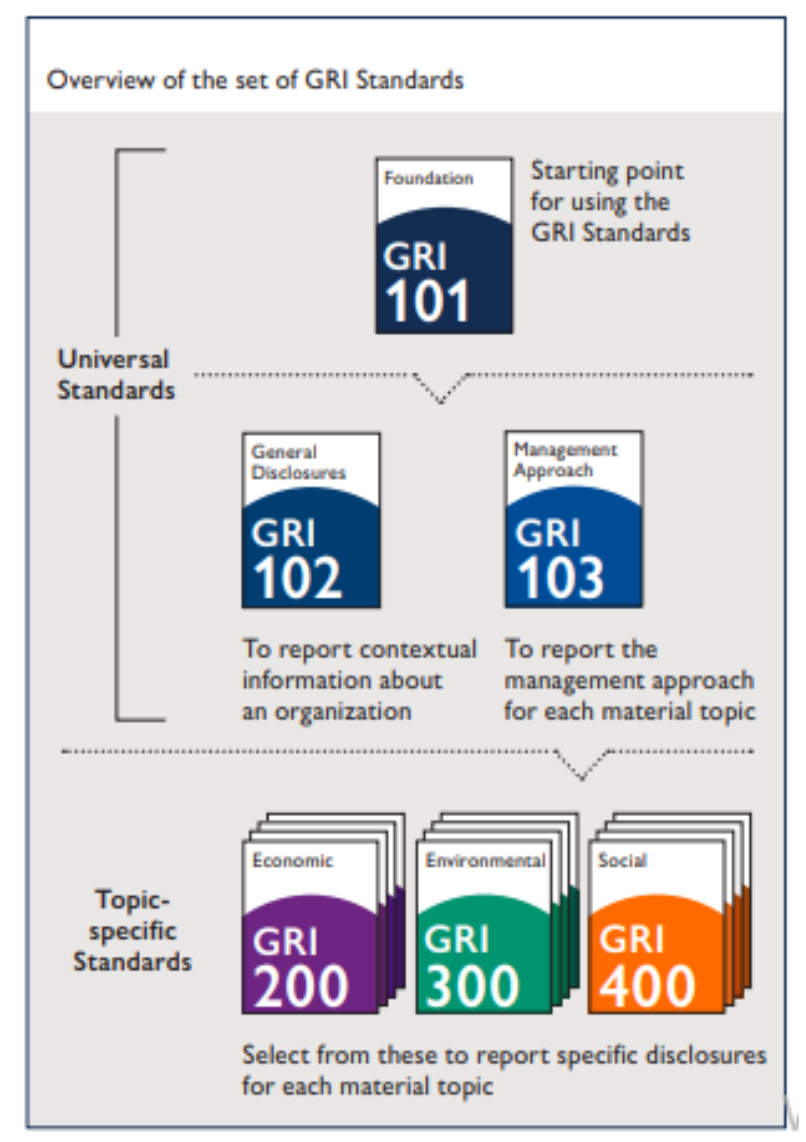

Şekil 1. GRI Standartlar Seti

Kaynak: Consolidated Set of GRI Sustainability Reporting Standards, 2020:3

GRI Standartlarına uygun hazırlanan bir rapor, bağımsız bir sürdürülebilirlik raporu olarak üretilebilir veya çeşitli formatlarda hazırlanabilir. Ancak GRI Standartlarına uygun olarak hazırlanan herhangi bir raporun, tüm açıklamaları için bir GRI içerik indeksi içermesi gerekir. Raporda açıklanan bilgilere GRI içerik kodlarına uygun referans verilmelidir. Gerekli bir bilgiye yer verilmediğinde nedeniyle açıklanmalıdır.

Sürdürülebilirlik raporunun GRI Standartlarına uygun olarak hazırlandığını iddia eden bir kuruluşun yüksek kaliteli sürdürülebilirlik raporlaması elde etmek için raporlama ilkelerini uygulaması gerekir. Raporlama ilkeleri rapor içeriğini oluşturan ilkeler ve rapor kalitesini oluşturan ilkeler olmak üzere iki gruba ayrılmıştır. Rapor içeriğini oluşturmaya yönelik raporlama ilkeleri, kuruluşların rapora hangi içeriğin dahil edileceğine karar vermesine yardımcı olur. Kuruluşun faaliyetlerini ve bu faaliyetlerinin etkilerini, paydaşlarının temel beklentilerini ve çıkarlarını dikkate almayı içerir (GRI 101, s.7). 
Tablo 1. Raporlama İlkeleri

\begin{tabular}{|c|c|}
\hline $\begin{array}{l}\text { Rapor içeriğini Oluşturan } \\
\text { Ilkeler }\end{array}$ & $\begin{array}{lll}\begin{array}{l}\text { Rapor } \\
\text { Illkeler }\end{array} & \text { Kalitesini } & \text { Belirleyen } \\
\end{array}$ \\
\hline $\begin{array}{l}\text { - Paydaş Kapsayıcılığı } \\
\text { - Sürdürülebilirlik Bağlamı } \\
\text { - Önemlilik } \\
\text { - Tamlık }\end{array}$ & $\begin{array}{l}\text { - Doğruluk } \\
\text { - Denge } \\
\text { - Netlik } \\
\text { - Karş1lasstırılabilirlik } \\
\text { - Güvenilirlik } \\
\text { - Zamanlılik }\end{array}$ \\
\hline
\end{tabular}

Rapor kalitesini belirlemeye yönelik ilkeler, sürdürülebilirlik raporundaki bilgiler ile paydaşların sağlıklı ve makul değerlendirme yapması ve uygun kararlar alması için önem arz etmektedir (GRI 101:7).

Uluslararası Çalışma Örgütü, sosyal, çevresel ve ekonomik yönleri içeren sürdürülebilirliğin kurumsal sosyal sorumluktan daha geniş bir kavram olduğuna ve kurumların toplum üzerindeki sorumluluğuna dikkat çekmiştir (www.csr-in-deutschland, 2020). Kurumlar için sürdürülebilirliği karmaşık hale getiren, sosyal ve çevresel gelişmeler ile gelecekteki beklentilerin kolayca standartlaştırılamayan çok boyutlu kavram olmasıdır (Nogueria vd., 2018: 275-299).

Türkiye'de kurumsal sürdürülebilirliğe yönelik düzenlemeler, 1999 yılında OECD tarafından yayınlanan "kurumsal yönetim ilkeleri” esas alınarak Sermaye Piyasası Kurulu'nun (SPK) yayınladığı Kurumsal Yönetim İlkeleri Tebliği ile boyut kazanmıştır (Gücenme ve Aytaç, 2016:58) . II-17.1 sayılı Kurumsal Yönetim Tebliği'nin 1'nci maddesinde yapılan değişiklikle borsada işlem gören şirketlerin 2021 yılından itibaren 2020 y1lı bilgilerini kapsayacak şekilde sürdürülebilirlik ilkeleri uyum çerçevesi kapsamındaki açıklamalara yer vermesi kararlaştırılmıştır. Kurula yeni başvuran şirketlerin ise paylarının işlem görmeye başladığı yılı izleyen yılın bilgilerini kapsayacak şekilde sürdürülebilirlik ilkeleri uyum çerçevesine yer vermesi uygun görülmüştür. Kurul tarafından ilan edilen sürdürülebilirlik ilkelerinin uygulanması gönüllülük esasına dayanmaktadır.

\section{SİGORTA SEKTÖRÜNÜN SÜRDÜRÜLEBILIIRLIKK RAPORLAMASI}

Sürdürülebilir sigortacılığın, sürdürülebilir kalkınmanın merkezi konumunda olduğu rahatlıkla söylenebilir. Sigorta şirketleri sürdürülebilir bir ekonominin dinamiklerini oluşturan yatırımcılara, işletmelere ve kuruluşlara, tasarruflarını değerlendirmeleri ve yatırımlara kanalize etmelerinde, risk üstlenerek güven vermektedir. Böylece yatırımları teşvik ederek üretkenliğin artmasında, ülkenin ekonomik büyüme ve gelişmesinde aktif rol oynamaktadırlar. Sigorta şirketleri karar vericilerin kendilerini bekleyen riskleri anlamalarına ve yönetmelerine, zarar yüklerini paylaşarak ekonomik çöküşlerini önlemelerine destek olan kilit bir mali sektördür.

Bireylerin ve kuruluşların riskleri yönetmelerinde, belirsizliği azaltarak sürdürülebilir gelecek sağlamalarında katalizör rol üstlenen sigorta şirketlerin sürdürülebilirlikleri ise, sosyal ve ekonomik açıdan kritik öneme sahiptir. Sigorta şirketlerinin kendi üzerlerindeki riskleri azaltmaları ve sürdürülebilirliklerini sağlamaları tüm toplumun yararına olacaktır. Ekonomik kalkınmanın kaldıracı konumundaki sektörünün yürürlükteki kanun, kural ve yönetmeliklere 
uygun finansal raporlamanın yanında zorunlu olmayan sürdürülebilir sigorta ilkelerini uygulamaları proaktif yaklaşımın gereğidir. Ekonomik birimleri belirsizlik korkusundan arındırma vizyonuyla hizmet sunan sigorta şirketlerinin de, sosyal ve çevresel sürdürülebilirliklerini kurum kültürünün DNA'sına yerleştirmelerini sağlamaları kaçınılmazdır.

Birleşmiş Milletler Çevre Programı Finans Girişimi (UNEP FI) 2006 yllında "Sigortacılık Çalışma Grubu"nu (Insurance Working Group-IWG) oluşturmuştur. Girişim, UNEP ve küresel finans sektörünün stratejik birliğidir. Birlik finansal kurumların sürdürülebilirlik uygulamalarının belirlenmesi, teşviki ve gerçekleştirilmesi misyonunu üstlenirken finansal performans ile çevresel ve sosyal sürdürülebilirlik konularını bütünleştiren küresel bir çerçeve sunmaktadır.

Sigortacılık Çalışma Grubu, başta Avustralya, Almanya, Japonya, Birleşik Krallık ve Amerika Birleşik Devletleri olmak üzere on altı ülkede; sigorta, reasürör ve brokerlerden oluşan özgün bir ittifak kurarak, kurumsal sorumluluğun tartışmasız önemli bir ayağı olan sürdürülebilirlik ilkelerinin başlangıç raporunu geliştirmiştir. IWG üyeleri, küresel sürdürülebilirlik konularını dokuz maddede belirlemişlerdir. Bunlar; iklim değişikliği, mikro sigorta, yaşam boyu gelir, sağlık, gelişmekte olan insan kaynaklı riskler, çevresel sorumluluk, doğal kaynaklar, geri dönüşüm, iç etkinliktir (www.tsev.org.tr, 2021).

2015 yılında Birleşmiş Milletler Çevre Programı ev sahipliğinde yapılan Uluslararası Sigorta Topluluğu Küresel Sigorta Forumu'nda, "Sürdürülebilir Sigorta Forumu’nun” oluşturulması önerilmiştir. "Sürdürülebilir Sigorta-2030” (Insurance 2030-Insurance for Sustainable Development) raporu yayınlanmıştır. Brezilya, Fransa, Hollanda, Güney Afrika, Birleşik Krallık, Kaliforniya ve Washington Eyaleti, sürdürülebilir sigorta forumu'nun oluşturulması sürecine destek vermiş ve sigorta sektöründe istikrarlı sigorta piyasaları geliştirmek ve sürdürmek amacıyla 2016 yılında "Sürdürülebilir Sigorta Forumu (Sustainable Insurance Forum -SIF)" kurulmuştur.

SIF'in uzun vadeli vizyonu, sürdürülebilirlik faktörlerinin etkili bir şekilde sigorta şirketlerinin düzenleme ve denetimine entegre edildiği küresel bir sigorta sistemidir. Çevresel, sosyal ve yönetimsel firsatları değerlendirmek ve paydaşlara olan sorumluluğu yerine getirmek üzere stratejik bir yaklaşım olan "sürdürülebilir sigorta forumu”nun çalışmaları; yeni ortaya çıan riskler üzerine araştırmaya, denetim uygulamaları hakkında bilgi paylaşımına, üst düzey politika katılımı ve ortak denetim beyanlarına, iklim konularında uluslararası işbirliğine dayanan dinamik bir platformdur. Birleşmiş Milletler Çevre Programı SIF sekreterliği olarak hizmet vermekte olup, Temmuz 2020 itibariyle, SIF'in 30 üye ülkesi bulunmaktadır (www.sustainableinsuranceforum.org/about, 2020).

Sürdürülebilir bir sigorta sektörü için sigorta düzenlemelerindeki son gelişmelerle ilgili olarak Solvency II'nin sürdürülebilirlikle ilgili gereklilikleri hakkındaki "Avrupa Parlamentosu ve Konsey Yönetmeliği (2019/2088)" finansal hizmetler sektöründe büyük önem taşımaktadır. Sigorta sektöründe sürdürülebilirlik riski, yatırımın değeri üzerinde olumsuz bir maddi etkiye neden olabilecek çevresel, sosyal veya yönetişim olayı veya koşulu anlamına gelmektedir (2009/65 / EC, 2009 / Direktifleri ${ }^{1}$ mad.14). Yönetmeliğin 5.

\footnotetext{
${ }^{1} 138$ / EC, 2011/61 / EU, 2013/36 / EU, 2014/65 / EU, (EU) 2016/97, (EU) 2016/2341
} 
maddesinde sürdürülebilirlik risklerinin entegrasyonu, olumsuz sürdürülebilirlik etkilerinin değerlendirilmesi, sürdürülebilir yatırım hedefleri, çevresel veya sosyal sürdürülebilirlik süreçleri ve yatırımcılara yapılan açıklamaların henüz uyumlaştırılamadığı vurgulanmaktadır. Yönetmelik uyarınca danışmanların bilgi vermeleri gerekmemekle birlikte, danışmanlık süreçlerinde sürdürülebilirlik risklerini dikkate almaları gerekmektedir (mad. 6). Birlik, iklim değişikliği, kaynakların tükenmesi ve diğer sürdürülebilirlikle ilgili sorunların yıkıcı ve öngörülemeyen sonuçlarıyla giderek daha fazla yüz yüze kalındığından, sermayeyi sadece kamu politikaları yoluyla değil, aynı zamanda finansal hizmetler sektörü tarafindan da harekete geçirmek için acil eylem planının gerekliliğine işaret etmektedir. $\mathrm{Bu}$ nedenle, finansal piyasa katılımcıları ve finansal danışmanların, sürdürülebilirlik risklerinin entegrasyonu ve olumsuz sürdürülebilirlik etkilerinin dikkate alınması konusundaki yaklaşımlarına ilişkin belirli bilgileri ifşa etmeleri istenmektedir (mad.8).

Sürdürülebilirlik raporlarının kurallar çerçevesinde açıklanmasına ilişkin uyumlaştırılmış düzenlemenin olmaması, ulusal düzeyde farklı önlemlerin benimsenmeye devam edilmesi, sektörde farklı yaklaşımların devam etmesini muhtemel kılmaktadır. Raporlama standartlarındaki önemli farkll1ıklar nedeniyle; rekabette önemli bozulmalar devam etmekte, farklı raporlama standartları ve piyasa temelli uygulamalar, karşılaştırmayı zorlaştırmakta, eşit olmayan bir oyun alanı yaratarak iç pazarda dahi ek engeller oluşturmaktadır. Bu tür farklılıklar karar vericiler için kafa karıştırıcı olabilmekte ve yatııım kararlarını bozabilmektedir.

4 Kasım 2016'da yürürlüğe giren "Birleşmiş Milletler İklim Değişikliği Çerçeve Sözleşmesi" kapsamında kabul edilen "Paris Anlaşması"na uyumun sağlanmasında, üye devletlerin farklı ulusal tedbirler alma riskleri üzerinde durulmuștur. Ayrıca şeffaflıkla ilgili uyumlaştırılmış kuralların eksikliği, karar vericilerin farklı üye devletlerdeki farklı finansal ürünlerin çevresel, sosyal ve yönetişim risklerinin sürdürülebilir yatııım hedefleri açısından etkin bir şekilde karşılaşıırmasının zorluğuna dikkat çekilmiştir. Bu nedenle, gelecekteki olası sıkıntılardan kaçınmak, iç pazarın işleyişinin önündeki mevcut engelleri ele almak ve finansal ürünlerin karşılaştııılabilirliğini artırmak için gerekli adımların atılması üzerinde durulmaktadır (mad. 9).

Yönetmelik "2009/65 / EC sayılı Direktiflerde”2 de öngörüldüğü şekilde, şirket yönetiminin karar vericilerin yarına olacak şekilde raporlama yapmalarının önemine işaret etmektedir. Yalnızca ilgili tüm finansal riskleri değil, aynı zamanda ilgili tüm sürdürülebilirlik risklerini de iş modellerine entegre ederek sürekli değerlendirmeleri önerilmektedir. Sürdürülebilirlik risklerinin nasıl entegre edileceği belirtilmeli ve bu politikalar yayınlanmalıdır (mad. 12). Sürdürülebilirlik risklerinin finansal ürünün performansını ne ölçüde etkileyebileceği, niteliksel veya niceliksel olarak açıklanmalıdır. Risk değerlendirmeleri ve ilgili raporlama öncesi açıklamalar, finansal danışmanlar tarafindan yapılan raporlama öncesi açıklamaları beslemelidir. Sürdürülebilirlik risklerinin olmadığı sonucuna varılması durumunda, bunun nedenleri de raporlarda açıklanmalıdır (mad. $15,20,22)$. Bu tür prosedürlere ilişkin bilgiler, finansal piyasa katılımcılarının sürdürülebilirlikle ilgili yönetim sorumluluklarını veya diğer hissedar sözleşmelerini nasıl yerine getirdiklerini açıklayabilir. Şirketler web sitelerinde bu prosedürler ve temel olumsuz

2 2009/138 / EC, 2011/61 / EU, 2013/36 / EU, 2014/65 / EU, (EU) 2016/97, (EU) 2016/2341 ve Yönetmelikler (AB) No 345/2013 ve (AB ) 346/2013 say1l 
etkilere ilişkin açıklamalara yer vermelidir (mad.18). Web sitelerinde yayınlanan bilgilerin güvenilirliğini sağlamak için, bu tür bilgiler güncel tutulmalı ve bu bilgilerde yapılacak herhangi bir revizyon veya değiş̧iklik açıkça raporlanmalıdır (mad. 26).

Sürdürülebilirlik kriterlerinin dikkate alınması, reel ekonominin direncini ve finansal sistemin istikrarını artırabilir. Karar vericilerin bilinçli yatırım kararları vermesinin sağlanması, risk-getiri üzerinde etkisi olabilir (mad. 19). Şirketler sürdürülebilir performansı ölçmek için hangi sürdürülebilir ölçütü kullandıklarını ve hiçbir ölçütün kullanılmadığı yerlerde, sürdürülebilir hedefin nasıl karşılandığını açıklamalıdır. Bu açıklamalar, periyodik raporlarla yıllık olarak yayınlanmalıdır (mad.21).

Birlik yasasında belirtilen raporlama ilkeleri, şirketlerin çevresel veya sosyal özelliklere sahip ürünlere yaptıkları yatırımların sürdürülebilirlikle ilgili etkileri hakkında gerekli tüm bilgilerin açıklanmasını gerektirmemektedir. Bu tür yatırımlara iliş̧kin daha spesifik ve standartlaştırılmış açıklama gerekliliklerinin belirlenmesini uygun görmektedir. Örneğin, sürdürülebilir yatırım hedefini ölçmek için ürünlerin sürdürülebilirlikle ilgili genel etkisi, ilgili göstergeler aracıllğıyla düzenli olarak raporlanmalıdır (mad.23). Avrupa Parlamentosu ve Konsey Direktifi 2013/34 / EU (18) kararında, finansal olmayan raporlamada çevresel, sosyal ve kurumsal yönetişim konularında şeffaflık yükümlülükleri getirmektedir (mad. 25). 27 Kasım 2019 tarihinde Strazburg'da düzenlenen yönetmelik Avrupa Birliği Resmi Gazetesi'nde (The Official Journal of the European Union) yayımlanmasını takiben 2021 y1lından itibaren yürürlüğe girecektir (www.eurlex.europa.eu/eli/reg/2019/2088/oj, 2021).

\section{BIST SIGORTA ŞIRKETLERIININ SÜRDÜRÜLEBILIIRLIKK AÇIKLAMALARI}

$\mathrm{Bu}$ bölümde çalışmanın amacı, metedolojisi ve analiz edilen bulgular hakkında bilgi verilmektedir.

\section{1. Çalışmanın Amacı ve Kapsamı}

Kurumsal sürdürülebilirlik raporu standardı çerçevesinde; sürdürebilirlik raporu hazırlayan şirketlerin söz konusu raporlarını, hazırlamayan şirketlerin ise faaliyet raporlarını inceleyerek uluslararası standartlara uygunlukları hakkında bilgiye ulaşmak, öncü sigorta şirketlerinin kendilerine özel sektör gerekliliklerini nasıl bir sürdürebilirlik örüntüsü içinde açıkladıklarını analiz etmek ve raporlamanın geleceği yönünde farkındalık sağlamak çalışmanın amacını oluşturmaktadır. Bu amaçla çalışmada, 2014-2020 yılları arasında BİST'de pay senetleri işlem gören sigorta şirketleri çalışma kapsamına alınmıştır (Tablo 2).

Tablo 2. Çalışma Kapsamındaki Sigorta Şirketleri

\begin{tabular}{|l|}
\hline Şirketler \\
\hline Aksigorta A.Ş \\
\hline Anadolu Anonim Türk A.Ş \\
\hline Anadolu Hayat Emeklilik A.Ş \\
\hline Avivasa Emeklilik ve Hayat A.Ş \\
\hline Ray Sigorta A.Ş \\
\hline Türkiye Sigorta A.Ş \\
\hline
\end{tabular}


2020 y1lı itibariyle ülkemizde hayat branşında prim üretimi bir önceki y1la göre yüzde 27 artışla 14,4 Milyar TL olarak gerçekleşirken, hayat dışı branşlarda prim üretimi yüzde 17,7 artışla 68,1 Milyar TL'ye ulaşmıştır. Aynı yıl itibariyle ödenen toplam tazminat tutarı 1 Milyar 279 Milyon TL'dir. BIST Sigortacilık Endeksi 2020 yılında, yüzde 72'lik bir performans ile BIST endeksleri arasında en iyi performansı gösteren endeksler arasında yer almıştır (ww.tsb.org.tr, 2021). Ülke ekonomilerine uzun soluklu kaynak sağlayarak ekonomik dalgalanmalara ve kırılganlıklara karşı stabilizatör işlevi gören sigorta şirketlerinin sürdürülebilirlikleriyle ilgili çalışmaları, rehber bir metodolojiyi takip ederek izlenmiştir. Kendine özel bir yapısı olan sektörün gelişmelerdeki rolü bütüncül bir yaklaşımla ele alınarak farkındalığın artması hedeflenmiştir.

\subsection{Araştırmanın Metodolojisi}

BİST sigorta şirketlerinin sosyal ve çevresel sürdürülebilirlik yaklaşımları doğrultusundaki stratejik açıklamaları, nitel araştırma yöntemi olan içerik analiziyle ele alınmış ve sektöre yönelik değerlendirme yapılmıştır.

\subsection{Bulgular}

Çalışma kapsamındaki sigorta şirketlerinden biri, 2018-2020 yıllarında BIST sürdürülebilirlik Endeksin'de yer almış ve "GRI Standartları: Temel" seçeneğine uyumlu olarak sürdürülebilirlik raporu yayınlamıştır. BİST'de yer alan diğer şirketler sürdürebilirlik raporu yayınlamamakla birlikte çevresel ve sosyal sürdürülebilirlik konusundaki duyarlılıklarını ve performanslarını, yıllık faaliyet raporlarında açıklamışlardır. Şirketlerin 2014-2020 yıllarını içeren faaliyet raporlarından, şirket vizyonuyla içselleştirdikleri çevresel ve sosyal sürdürülebilirlik konularında yaptıkları açıklamalara ilişkin elde edilen bulgular, çevresel sürdürülebilirlik bulguları ve sosyal sürdürülebilirlik bulguları olarak ele alınmıştır.

\subsection{1. Çevresel Sürdürülebilirlik Bulguları}

Sigorta şirketleri risk modelleriyle destekledikleri ürün ve hizmetlerini müşterilerinin menfaatlerine sunarken sürdürülebilirlikleri, müşterilerinin sürdürülebilirliklerine ilintili kendine özgü bir örüntü içindedir. Şirketler çevresel sürdürülebilirlik konusunda, çevre ve iklim değişikliğine yönelik stratejik yaklaşımla öne çıkmaktadırlar. Çevreye karşı hassasiyet içeren ürün ve hizmet yelpazesiyle müşterilerinin sürdürülebilirliklerine katkıda bulunurken kendi asli faaliyetlerinin yanında çevresel duyarlılıkları hakkında karar vericileri de bilgilendirerek sürdürebilirliklerini sürekli kılma çabası içindedirler.

Çalışma kapsamındaki 1 sigorta şirketinin 2018 yılından itibaren GRI-4 standartları kapsamında yayınladığı sürdürülebilirlik raporu diğer 5 şirketin ise yayınladıkları faaliyet raporları esas alınarak yapılan içerik analizi sonuçları Tablo 3'de gösterilmiştir. 
Tablo 3. Açıkladıkları Çevresel Sürdürülebilirlik İçeriklerine Göre Şirketlerinin Sayısal Dă̆ı̆ımları

\begin{tabular}{|l|c|c|c|c|c|c|c|}
\hline Çevresel Sürdürülebilirlik & $\mathbf{2 0 1 4}$ & $\mathbf{2 0 1 5}$ & $\mathbf{2 0 1 6}$ & $\mathbf{2 0 1 7}$ & $\mathbf{2 0 1 8}$ & $\mathbf{2 0 1 9}$ & $\mathbf{2 0 2 0}$ \\
\hline $\begin{array}{l}\text { Sürdürülebilir bir çevre için duyarlılık } \\
\text { açıklamaları }\end{array}$ & 1 & 1 & 2 & 3 & 4 & 5 & 5 \\
\hline Sıfır sera gazı emisyonu-düşük karbon salınımı & - & - & - & 1 & 2 & 2 & 3 \\
\hline Enerji yönetimi- iklim değişikliğine duyarlılık & 1 & 1 & 1 & 1 & 3 & 4 & 5 \\
\hline Enerji üretim sistemi & 1 & 1 & 1 & 1 & 1 & 1 & 1 \\
\hline Malzeme tüketimi ve atık yönetimi & - & - & 1 & 2 & 2 & 3 & 3 \\
\hline
\end{tabular}

İçerik analizi yöntemiyle incelenen faaliyet raporlarında, son y1llarda çevresel duyarlılık açıklamalarının arttığı tespit edilmiştir. Bir şirketin faaliyet raporunda bu konuda ifadelere yer verilmemiştir. Hizmet sektörü olan şirketlerin iklim değişikliğine olan etkileri, enerji tüketimi boyutunda değerlendirilmiştir. Enerji yönetimi için tüketim noktalarının tespiti ve kontrolüne ağırlık verildiğine yönelik açıklamalar özellikle 2018 yılı itibariyle artmıştır. Enerji kullanımı kaynaklı sera gazı emisyonları, karbon ayak izini azaltma projelerine dayanan açıklamalar 2017 yılında bir şirket ile başlamıştır. Çalışmada özellikle dikkat çeken durum, bir şirketin bir konudaki açıklamalarına izleyen yılda yer vermemesi daha sonraki yılda ise tekrar bildirimlerde bulunmaya devam etmesidir. Diğer bir değişle açıklamalar her konuda süreklilik arz etmemektedir. Bu durum yıllar içinde şirketlerin karşılaştırılabilmesine de engel oluşturmaktadır. Örneğin, sıfır sera gazı emisyonu-düşük karbon salınımı konusunda farklı yıllarda farklı şirketlerin açıklamalarına ulaşııııştır. 2018 yılında Anadolu Sigorta Şirketi konu hakkında ilk kez açıklama yapmış, 2019 yılında ise herhangi bir açıklamaya rastlanmamıştır. Ancak şirketin 2020 yılında tekrar açıklamalara yer verdiği izlenmiş̧ir. 2019 y1lında söz konusu açıklamalarla ilgili Ak Sigorta ve Avisa Sigorta Şirketi bilgi verirken 2020 y1lında Avisa Sigorta Şirketi ile Anadolu Hayat Emeklilik Sigorta Şirketi'nin bilgilerine ulaşılamamıştır.

Çalışmada, bir şirketin kendi enerji üretim sistemini kurduğu ve sürdürdüğü tespit edilmiş̧tir. Sürdürülebilir bir çevre için şirketlerin üzerinde durduğu önemli bir konuda, faaliyetlerinin özelliğine bağlı malzeme tüketimi olan kağıttır. Şirketler yasaların izin verdiği ölçüde poliçe ve yazışmalarını dijital ortamda gerçekleştirdiklerini, kullanılan kağıtların ise geri dönüşümüne ağırlık verdiklerini açıklamışlardır. Son yıllarda atık yönetimiyle ilgili çalışmalara daha fazla şirketin duyarlılık gösterdiği açıklamalarda izlenmiştir.

\subsubsection{Sosyal Sürdürülebilirlik ile İlgili Bulgular}

Sosyal sürdürülebilirlik, şirketin çalışma standartlarının, ekonomik kalkınma ve insan hakları üzerindeki olumlu ve olumsuz etkilerini açıklamayı gerektirir (Jhunjhunwala, 2014: 73-80) .

Sigorta şirketlerinin sosyal sürdürülebilirlikle ilgili açıklamalarına yer verildiği bu bölümde, şirketlerin faaliyet raporlarında yer verilen açıklama içerikleri esas alınarak Tablo 4 düzenlenmiştir. 
Şirketlerin faaliyet raporlarında sigortacılık sektörünün geleceği ve "Kurumsal Yönetim Uyum Raporu" ile ilgili detaylı bilgi verilmiştir. 2018 yılında ilk kez sürdürülebilirlik G4 standartlarına uygun rapor sunan bir şirket, "Birleşmiş Milletler Küresel İlkeler Sözleşmesi” üyesi olduğunu, sürdürülebilirlik raporunun aynı zamanda ilerleme bildirimi yerine de geçtiğini beyan etmiştir. Çalışanların iş sağlığına yönelik bildirimlere, her dönem olmasada, yer verilen raporlarda özellikle mesleki eğitim ve iş ahlakına verilen önem ve düzenlenen eğitim içerikli etkinlikler geniş yer bulmuştur.

Tablo 4'de görüldüğü üzere "ISO 10002 Standardıyla Uyumlu Müşteri Memnuniyeti Yönetim Sistemi” açıklamaları en fazla 2018 yılı raporlarında beyan edilmiştir.

Toplumsal sorumluluk projelerinde hemen tüm şirketlerin açıklamaları yer almıştır. Örneğin; dezavantajlı çocukların rehabilitasyonu için "Türkiye Çocuklara Yeniden Özgürlük Vakfı" ile işbirliği, deniz araçlarının sigorta gelirlerinin belirli bir kısmının "Deniz Temiz Derneği/Turmepa" ya ödenmesi, "Engelsizler Kültür Sanat ve Eğitim Merkezi (TEKSEM)" ile yürütülen işbirliği çerçevesinde Türkiye'nin farklı bölgelerinde sergilenen tiyatro oyunları gelirlerinin engelli çocukların ihtiyaçları için tahsis edilmesi, açıklamalardan bazılarıdır.

Teknoloji odaklı gelişmelerin yakından takip edilmesine, hizmet ve ürünlerin dijitalleşmesiyle ilgili bilgilendirme açıklamalarına son yıllarda daha fazla ağırlık verildiği izlenmiştir.

Bir önceki bölümde de ifade edildiği gibi, şirketlerin bazı konulardaki açıklamalarına periyodik olarak yer vermedikleri tespit edilmiştir. Örneğin; Ak Sigorta Şirketi 2018 yılında "ISO 10002 Standardıyla Uyumlu Müşteri Memnuniyeti Yönetim Sistemi” hakkında bilgi vermiş olmakla birlikte, bu bilgiye 2019 yılında ulaşılamamıştır. Benzer şekilde, "Sosyal yaşam ve spor etkinlikleri" konularında verilen bilgiler 2019 yılında tespit edilememiştir. Ayrıca bazı konularda verilen bilgiler için şirketlerin ayrı başlık açmadığı ve konuların bir cümle ile ifade edildiği de dikkat çekmektedir. İş etiği, iş sağlığı ve güvenliği, sosyal yaşam, iş ortakları performans etkinlikleriyle ilgili bilgilere genel olarak konular içinde yer verildiği görülmüştür. Çalışmanın güvenilirliği açısından, şirket yetkilileriyle istişarede bulunulmuş her yıl düzenli olarak bilginin verilmemiş olması ve ayrı başlıklar altında sunulmamış olması bir eksiklik olarak değerlendirilmiştir. Bu durum bilgiye hızı bir şekilde ulaşılmasını ayrıca hem şirket bazında hemde şirketler arasında karşılaştırma yapılmasını zorlaştırmaktadır.

Tablo 4. Açıkladıkları Sosyal Sürdürülebilirlik İçeriklerine Göre Şirketlerinin Sayısal Dağılımları

\begin{tabular}{|l|l|l|l|l|l|l|l|}
\hline Sosyal Sürdürülebilirlik & 2014 & 2015 & 2016 & 2017 & 2018 & 2019 & 2020 \\
\hline $\begin{array}{l}\text { Sigortacılık sektörünün geleceğine yönelik } \\
\text { açıklamalar }\end{array}$ & 6 & 6 & 6 & 6 & 6 & 6 & 6 \\
\hline Kurumsal Yönetim Uyum Raporu & 6 & 6 & 6 & 6 & 6 & 6 & 6 \\
\hline $\begin{array}{l}\text { Birleşmiş Milletler Sürdürülebilir Kalkınma } \\
\text { Hedefleri }\end{array}$ & - & - & - & - & 1 & 1 & 1 \\
\hline İş sağlığı ve güvenliği & 3 & 2 & 2 & 4 & 5 & 2 & 4 \\
\hline İnsan kaynakları politikası & 5 & 4 & 4 & 6 & 6 & 3 & 4 \\
\hline İş etiği ve eğitim & 5 & 4 & 4 & 6 & 6 & 6 & 4 \\
\hline Sosyal yaşam -spor- etkinlikler & 2 & 3 & 2 & 2 & 6 & 3 & 2 \\
\hline $\begin{array}{l}\text { ISO 10002 standardıyla uyumlu müşteri } \\
\text { memnuniyeti yönetim sistemini }\end{array}$ & 2 & 2 & 2 & 1 & 4 & 2 & 2 \\
\hline
\end{tabular}




\begin{tabular}{|l|l|l|l|l|l|l|l|}
\hline Müşteri ilişkileri ve gizliliği & 2 & 3 & 3 & 3 & 2 & 5 & 3 \\
\hline İş ortakları performans etkinlikleri & 2 & 1 & 1 & 2 & 3 & 2 & 1 \\
\hline $\begin{array}{l}\text { Toplumsal sorumluluk projeleri -uluslararası ilkeler } \\
\text { cerçevesinde rüssvet ve yolsuzlukla mücadele - suç } \\
\text { gelirlerinin aklanması }\end{array}$ & 5 & 3 & 3 & 6 & 5 & 5 & 4 \\
\hline $\begin{array}{l}\text { Dijitalleşme projeksiyonları -teknoloji odaklı girişim } \\
\text { faaliyetleri- dijital hizmet proje uygulamaları }\end{array}$ & 4 & 3 & 4 & 4 & 6 & 5 & 6 \\
\hline
\end{tabular}

\section{SONUÇ}

Dünyada gelişen ekonomik küreselleşme, sermaye piyasalarının devinimliği, şirketlerin uluslararası boyut kazanması, kuruluşların faaliyet gösterdiği mecralardaki ticari, sosyal ve çevresel gelişmeleri yansıtabilen bilgi talebini öne çıkarmıştır. 1980'li yıllarda kurumsal sosyal sorumluluk ve çevresel bilgilendirme açıklamalarıyla öne çıkan farkındalık, 2000'li yıllarda sürdürülebilirlik raporlamaları ile standartlara kavuşmuştur. Merkezi Hollanda'da bulunan Küresel Raporlama Girişimi tarafından belirlenen standartlar rehber taslağı, revize çalışmalarıyla G4 standartları boyutuna ulaşmıştır. Genel bir perspektif sunma misyonuyla başlayan standartlar sektörel olarak raporlanacak alanları standardize etme konumuna gelmiştir.

Yapılan literatür taramasında birçok ülkede şirketlerin henüz yasal bir mevzuata kavuşmasa da gönüllülük esasına göre, beklenti içinde olan tarafları bilgilendirmek amacıyla; ya sürdürülebilirlik raporları yayınlamakta olduğu yada faaliyet raporlarında sürdürülebilirlik çerçevesinden hareketle bilgilendirmelere yer verdikleri görülmüştür.

Raporlama ilkelerinin niteliği gereği raporlarda sunulan bilgilerin; karşılaştırılabilir, doğru, dengeli, zamanında, güvenilir ve netlik kriterlerine uygun hazırlanması gerekir. İlkelere uygun hazırlanan raporlarda yer alan bilgilerin kalitesi, tüm tarafların şirket performansı hakkında doğru ve makul değerlendirme yapmalarını sağlamak açısından önemlidir.

Çalışmada, BİST de pay senetleri işlem gören 6 sigorta şirketinin sürdürülebilirlik açıklamaları sektörel düzeyde incelenmiştir. Kamuyu Aydınlatma Platformu'ndan elde edilen bilgiler doğrultusunda değerlendirme yapılmıştır. Şirketlerin faaliyet raporlarında açıkladıkları çevresel ve sosyal sürdürülebilirliği kapsayan bilgilere göre içerik oluşturulmuştur. Şirketlerden birinin 2018-2020 yıllarında GRI standartlarına uygun sürdürülebilirlik raporlaması yayınladığı diğer şirketlerin ise faaliyet raporlarında sürdürülebilirlik göstergelerine ayrıntılı olarak yer verdikleri tespit edilmiştir. GRI sürdürülebilirlik standartlarının genel çerçevesine uygun açıklamalara yer verilen faaliyet raporlarında özellikle, tüm şirketlerin sektöre özgü ve sektörün geleceğine yönelik bilgilere ayrıntılı yer verdikleri görülmüştür. Çevresel sürdürülebilirlik konusunda şirketlerin gelecek nesillere karşı duyarlılıkları izlenmiştir. Şirket boyutunda; iklim ve su krizi, atık sorunu ve sıfır sera gazı emisyonu-düşük karbon salınımı projelerine destek vermektedirler. Şirketler, özellikle bu konulardaki sigorta faaliyetlerinden sağlanan gelirlerinin bir kısmını, dernek ve vakıfların yürüttüğü projelerde kullanmaktadırlar. Şirketlerin sosyal sürdürülebilirlik kapsamındaki açıklamarı; ISO 10002 standardıyla uyumlu müşteri memnuniyeti yönetim sistemi, çalışanların iş sağlığ ve güvenliği, eğitim ve meslek etiği, toplumsal sorumluluk 
projeleri, uluslararası ilkeler çerçevesinde rüşvet ve yolsuzlukla mücadele, suç gelirlerinin aklanması ve teknoloji odaklı girişim faaliyetleridir.

Şirketlerin faaliyet raporlarında çevresel ve sosyal sürdürülebilirlikle ilgili açıklamalarının yıllar itibariyle belirli bir eğilim içinde olduğu incelenmiş olsa da, bazı konulara her yıl yer verilmediği, diğer bir değişle istikrarlı bir süreklilik arz etmediği dikkat çekmiştir. Kuruluşların değer yaratma süreci ile ilgili potansiyelinin nitelik ve verimliliğini ölçmek ve değerlendirmek bilgi kullanıcılarının karar vermelerinde yol gösterici olmaktadır. Hal böyleyken açıklamaların şirket özelinde dahi belirli bir formattan uzak olması, sektörel bazda şirketlerin karşılaştırılması bir tarafa, yıllar itibariyle şirketlerin kendi içlerinde karşılaştırılmasını dahi sınırlandırmakta olduğu tespit edilmiştir.

Çalışmada, sürdürülebilirliğin kavramsal boyutu ve sigorta sektöründe sürdürülebilirlik raporlaması ile ilgili gelişmeler proaktif yaklaşımla değerlendirilmiştir. Çalışmanın, sigorta sektörüyle ilgili gelecekte yapılabilecek çalışmalara ivme kazandıracağı beklenmektedir.

\section{KAYNAKLAR}

Consolidated Set of GRI Sustainability Reporting Standards (2020), www.globalreporting.org/how-to-use-the-gri-standards/gri-standards-englishlanguage/, (27.12.2020).

EU Regulation, 2019/2088 of the European Parliament and of the Council of 27 November 2019 on sustainability-related disclosures in the financial services sector (Text with EEA relevance).

Gücenme Gençoğlu, Ümit -Aytaç, Alp (2016), “ Kurumsal Sürdürülebilirlik Açısından Entegre Raporlamanın Önemi ve BIST Uygulamaları", Muhasebe ve Finansman Dergisi, 72, ss.51-66.

Jhunjhunwala, Shital (2014), "Beyond Financial Reporting International Integrated Reporting Framework”, Indian Journal of Corporate Governance, January 1, pp. 73-80.

Kolk, Ans (2010), “Trajectories of Sustainability Reporting by MNCs”, Journal of World Business, 45, pp. 367-374.

Kurumsal Yönetim Tebliği (II-17.1), 3/1/2014 tarihli ve 28871 say1lı Resmî Gazete (2/10/2020 tarihli ve 31262 sayılı Resmî Gazete'de yayımlanan (II-17.1)’nde değişiklik yapılmasına dair Tebliğ (II-17.1.a)).

Maltby, John (2004), "Hadfields Ltd: its Annual General Meetings 1903-1939 and their Relevance for Contemporary Corporate Social Reporting”, British Accounting Review, 36 ( 4), pp.415-439.

Nogueira, Flávio G- Lucena, André F.P- Nogueira,Roberto (2018), “Sustainable Insurance Assessment: Towards an Integrative Model" The Geneva Papers on Risk and Insurance - Issues and Practice, Palgrave Macmillan;The Geneva Association, 43(2), pp. 275-299. 
Roca, Laurence Clément - Searcy, Cory (2012), “An Analysis of Indicators Disclosed in Corporate Sustainability Reports”, Journal of Cleaner Production, 20 (1), pp.103-118.

www.csr-in-deutschland.de/EN/What-is-CSR/Background/Sustainability-and-CSR/ sustainability-and-csr-article.html, (10.12.2020).

www.tsev.org.tr, (10.03. 2021).

www.tsb.org.tr/, (10.03. 2021).

www.pwc.com/sg/en/publications/sustainability-report-2019.html, (26.12.2020).

www.globalreporting.org/about-gri/mission-history/, (26.12.2020).

www.sustainableinsuranceforum.org/about/, (02.02.2021).

www.eur-lex.europa.eu/eli/reg/2019/2088/oj, (10.03.2021). 